\title{
Lupin Seed for the Crop-Livestock Food Chain
}

\author{
Fabio Gresta*1, Valerio Abbate ${ }^{1}$, Giovanni Avola ${ }^{2}$, Giuseppe Magazzù ${ }^{3}$, \\ Biagina Chiofalo ${ }^{4}$ \\ ${ }^{1}$ Dipartimento di Scienze Agronomiche, Agrochimiche e Produzioni Animali - Sez. Scienze Agronomiche, \\ Università di Catania, Via Valdisavoia 5, 95123 Catania, Italy \\ ${ }^{2}$ CNR - Istituto per i Sistemi Agricoli e Forestali del Mediterraneo, Str.le V. Lancia, \\ Blocco Palma I, 95121 Catania, Italy \\ ${ }^{3}$ Consorzio di Ricerca Filiera Carni, Polo Universitario Annunziata, 98168 Messina, Italy \\ ${ }^{4}$ Dipartimento di Morfologia, Biochimica, Fisiologia e Produzioni Animali, Sezione Zootecnica e \\ Nutrizione Animale, Università di Messina, Polo Universitario Annunziata, 98168 Messina, Italy
}

Received: 4 September 2009. Accepted: 7 June 2010.

\begin{abstract}
The ban on animal protein supplements in animal nutrition and, particularly, the increase in the demand for alternative protein sources to replace soybean meal in organic farming has stimulated research on GM-free feeds and renewed interest in grain legumes. Of these lupin appears to be one of the more interesting and promising crops for ruminant diets, due to its key role in low-input cropping systems and its high protein content. The aim of this study was to evaluate the productive and nutritional characteristics of several sweet varieties of lupin seeds cultivated in the Mediterranean region. The trial was carried out during the years 2007/08 on a volcanic soil in East Sicily, employing 8 sweet cultivars belonging to Lupinus albus, L. angustifolius and L. luteus species. Yield and its components (pod plant ${ }^{-1}$, seed pod $^{-1}, 1000$ seed weight) were evaluated. Crude protein, fibre fractions and alkaloid content were also determined. L. albus exhibited the highest yields $\left(2.2 \mathrm{t} \mathrm{ha}^{-1}\right)$, with an intermediate value of pod $\mathrm{x}$ plant (15.4). L. luteus yielded $1.5 \mathrm{t} \mathrm{ha}^{-1}$ and L. angustifolius $0.5 \mathrm{t} \mathrm{ha}^{-1}$. L. luteus showed higher levels of crude protein $(34.2 \%)$ although the greatest protein yield per hectare was recorded in L. albus $\left(0.7 \mathrm{t} \mathrm{ha}^{-1}\right)$. L. angustifolius showed the highest mean values of NDF $(28.1 \%)$ and ADF $(25 \%)$, whereas L. luteus the lowest mean values of ADL (1.75\%). Six alkaloids were detected and quantified, among which, the Iso-lupanine always was the most abundant $\left(1.5 \mathrm{mg} 100 \mathrm{~g}^{-1}\right.$, on average). Lower concentrations of quinolizidine were observed in L. luteus $(0.9-1.4 \mathrm{mg}$

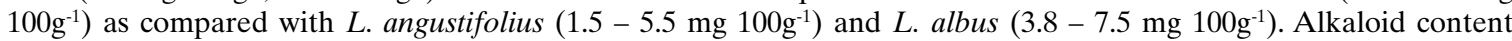
was always lower than the safe limit of toxicity $(<0.20 \%)$ indicated for human and animal consumption.
\end{abstract}

Key-words: Lupins, yield, protein, fibre fractions, alkaloids.

\section{Introduction}

The ban on animal protein supplements (European Commission Decisions No. 98/272/CE and 2000/374/CE) has increased the need to research different feeding systems able to satisfy the dietary requirements of livestock whilst safeguarding the quality of animal production (Vicenti et al., 2009). This has induced farmers to use soybeans which have a particularly high protein content and are therefore one of the most used and valuable components in ruminant and non ruminant feed formulation (Woodworth et al., 2001; Graham et al., 2002;
Kerley and Allee, 2003). However, the ban on use the soy which comes from genetically modified crops in organic farming (Reg. CE 1804/99), has greatly stimulated research on GM-free feeds, which are able to satisfy protein requirements in animal nutrition, and renewed the interest in low input grain legumes, especially for eco-sustainable crop-livestock systems. Moreover grain legumes are strategically important not only in decreasing the marked deficit of high-protein feedstuff (Annicchiarico and Carroni, 2009), but also in increasing the sustainability of crop-livestock systems through the safeguarding of soil fertility, the reduction

* Corresponding Author: Fax: +39 095 234449. E-mail address: fgresta@unict.it 
of greenhouse gas emission, and the reduction of nitrogen fertilizers use, etc. (Carrouée et al., 2003; Jensen and Hauggaard-Nilesen, 2003). Last but not least, the increase of domestic production of GMO-free plant proteins represents a way to reduce Italian dependence on feedstuff imports. Among legumes, lupin appears to be an interesting and promising crop. Since it has a winter cycle, it may play a key role in crop rotation (Postiglione et al., 1995) especially as it has a high protein content compared to the other winter legumes (Hill, 1977; Sujak et al., 2006). These characteristics increased its use in ruminant diet, since lupin can replace soybean meal even for high-producing lactating cows (van Barnelveld, 1999; Froidmont and Bartiaux-Thill, 2004). In addition, lupin has been studied as a human foodstuff (Reinhard et al., 2006) because of its potential to be used as an ingredient in functional and healthy food products due to its hypocholesterolaemic potential (El-Adawy et al., 2001; Duranti et al., 2008). However, spontaneous lupins contain many antinutritional components such as saponins, tannins and flavonoids (Sirtori et al., 2004). It also has bitter principles. Among these, more than 150 alkaloids of the quinolizidine, piperidine and indole group are known to appear at concentrations up to $6 \%$, conferring resistance to pathogens and grazing (Wink, 1988). For this reason, plant breeders have developed so called "sweet lupins" with low alkaloid content (below $0.05 \%$ ), for human and animal diet (Reinhard et al., 2006).

Lupin is, widely cultivated in Central and Eastern Europe and in Australia, but almost absent in the Mediterranean basin (Faostat, 2009) due, above all, to its restricted soil adaptability (acid or sub-acid soil). Anyway, in many Mediterranean environments this species could represent an alternative crop, especially in agricultural systems oriented toward organic productions with high traceability (Abbate, 2001; Arnoldi, 2004; Scarafoni et al., 2007).

Nowadays, the economic sustainability of this legume depends on its ability to maintain or reduce its alkaloid content and to increase its grain yield (Dronne, 2003). With this in mind, the aim of this study was to evaluate the productive and nutritional characteristics of eight sweet varieties of lupins (L. albus, L. angustifolius and L. luteus) cultivated in the Mediterranean environment. Particular attention was paid to the detection and quantification of the quinolizidine alkaloids, in order to promote the use of this crop within the Mediterranean livestock food chain.

\section{Materials and methods}

The trial was carried out in 2007/08 on a volcanic soil in East Sicily, Italy (Acireale, CT, 16 $\mathrm{m}$ a.s.l.) whose characteristics are reported in Table 1, using 8 sweet cultivars belonging to Lupinus albus, L. angustifolius and L. luteus (table 2). Plots of $6 \mathrm{~m}^{2}(3 \times 2 \mathrm{~m}) 3$ times replicated in a randomized block design were adopted. Sowing was executed on 27 December 2007

Table 1. Main characteristics of soil.

\begin{tabular}{lr}
\hline Sand $(\%)$ & 84.80 \\
Silt $(\%)$ & 9.90 \\
Clay $(\%)$ & 5.30 \\
$\mathrm{pH}$ & 8.5 \\
$\mathrm{~N}$ total $(\%)$ & 1.8 \\
$\mathrm{P}_{2} \mathrm{O}_{5}$ total $(\mathrm{ppm})$ & 167.72 \\
$\mathrm{~K}_{2} \mathrm{O}$ exchang. $(\mathrm{ppm})$ & 788.31 \\
Conductivity $\mu \mathrm{S} / \mathrm{cm} 25{ }^{\circ} \mathrm{C}$ & 770 \\
Organic carbon $(\%)$ & 3.11 \\
Total limestone $(\mathrm{g} / \mathrm{kg})$ & 30.0 \\
\hline
\end{tabular}

Table 2. Provenance of the different varieties of lupin.

\begin{tabular}{llll}
\hline Latin name & Common name & Cultivars & Provenience \\
\hline L. albus & White lupin & Luxor & Australia \\
L. albus & White lupin & Rosetta & Australia \\
L. angustifolius & Narrow-leafed lupin & Wonga & Australia \\
L. angustifolius & Narrow-leafed lupin & Jindalee & Australia \\
L. angustifolius & Narrow-leafed lupin & Sonet & Poland \\
L. luteus & Yellow lupin & Dukat & Poland \\
L. luteus & Yellow lupin & Mister & Poland \\
L. luteus & Yellow lupin & Taper & Poland \\
\hline
\end{tabular}


with a plant density of 80 plant $\mathrm{m}^{-2}$ on a ploughed and fertilized soil with $120 \mathrm{~kg} \mathrm{ha}^{-1}$ of $\mathrm{P}_{2} \mathrm{O}_{5}$. Seeds were harvested on 28 May 2008 for all varieties. Plant height and yield components (pod plant ${ }^{-1}$, seed $\mathrm{x} \mathrm{pod}^{-1}$ and 1000 seed weight) were evaluated using ten plants for each plot, while total yield was determined on the two central rows of the plot. The date of the main growth stages was also recorded according to the scale proposed by Dracup and Kirby (1996).

Crude protein content and fibre fraction (Neutral Detergent Fibre, Acid Detergent Fibre, Acid Detergent Lignin) percentages were determined using AOAC official methods of analysis (2005).

Alkaloids were extracted as described by Muzquiz et al. (1994). As control for the alkaloid content, we used Lupinus albus L. var. Multitalia, an Italian old sweet variety. Two grams of defatted bean flour were homogenized with an Ultraturrax homogeniser for $1 \mathrm{~min}$ in $20 \mathrm{~mL}$ of trichloroacetic acid (5\%) and centrifuged at $700 \mathrm{~g} \mathrm{~min}^{-1}$ for $5 \mathrm{~min}$. The extraction was repeated twice and the supernatants decanted while the precipitate was discarded (Oboh et al., 1998). The alkaloids in the sample extract were extracted with dicholorometane and analysed by HRGC-MS (Nossack et al., 2000) performed using a 5973 inert mass selective detector (Agilent technologies USA), coupled to a $6890 \mathrm{~N}$ GC (Agilent technologies USA). The capillary column used was a 95\% methyl, 5\% phenylpolysiloxane, HP-5 (Agilent J\&W GC Columns) of $30 \mathrm{~m}$ length, $0.25 \mathrm{~mm}$ i.d., $0,25 \mu \mathrm{m}$ film thickness. Samples were injected using the split mode (1:10) and the injection volume was $1 \mu \mathrm{l}$, the injection temperature was $240{ }^{\circ} \mathrm{C}$, with HRGC-MS interface temperature both at 250 ${ }^{\circ} \mathrm{C}$. The acquisition was from $\mathrm{m} / \mathrm{z}, 50$ to 300 and the source operated in EI mode at $70 \mathrm{ev}$. The column temperature was programmed to rise from $150{ }^{\circ} \mathrm{C}$, at $5{ }^{\circ} \mathrm{C} / \mathrm{min}$, to $235^{\circ} \mathrm{C}$ (held during $15 \mathrm{~min}$ ). Helium was used as carrier gas, at the average linear velocity of $35 \mathrm{~cm} / \mathrm{sec}$ and at a flow of $1 \mathrm{~mL} / \mathrm{min}$.

The alkaloids (Sparteine, Angustifoline, Lupanine, a-Iso-lupanine, 13 a-Hydroxylupanine and 11,12-Deidrelupanine) quantification was performed in full-scan mode by internal standard method using caffeine as an analytical standard. Lupinus extracts were diluted to 1.0 $\mathrm{mL}$ in methanol and $0.3 \mathrm{~mL}$ of a caffeine stan- dard solution ( $\left.1 \mathrm{mg} \mathrm{mL}^{-1}\right)$ was added to the sample, which was analysed by GC-MS (Nossack et al., 2000). In the standard solutions the Limit Of Quantification (L.O.Q.; S/N > 7) was of $0.02 \mathrm{mg}$ $100 \mathrm{~g}^{-1}$ for Sparteine and $0.04 \mathrm{mg} 100 \mathrm{~g}^{-1}$ for all other alkaloids.

All data were submitted to the analysis of variance. When ANOVA indicated a significant treatment effect, Tukey's HSD test was performed to determine which treatment means differed significantly. Moreover, Principal Component Analysis (PCA) was performed on productive and nutritional parameters (StatistiXL Software). Principal components with eigenvalues $>1.0$ were selected and correlation values $>0.6$ were considered as relevant for the PCA.

\section{Results and discussion}

Biological cycle lasted 153 days for all the varieties studied (Fig. 1). Differences arose when the single stages were taken into account. Early flowering was recorded in Luxor of L. albus, Sonet of L. angustifolius and Taper of L. luteus (63-66 days after emergence), while late flowering (74 days after emergence) was recorded on Jindalee of $L$. angustifolius and Dukat of L. luteus.

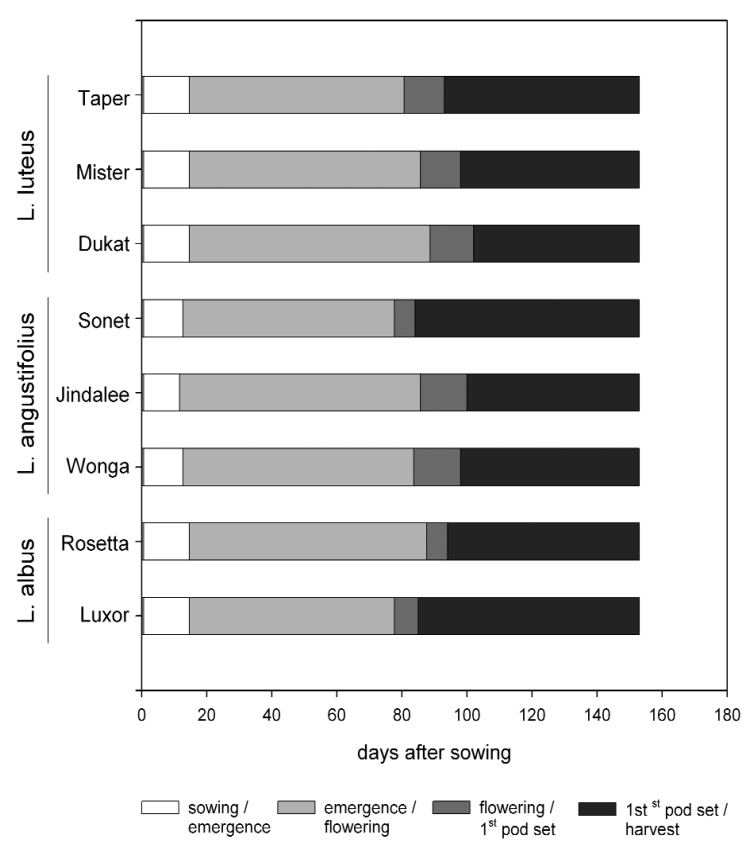

Figure 1. Duration of the main phenological stages of the studied varieties. 
Table 3. Main agronomic traits of the studied varieties of lupin.

\begin{tabular}{lcccccc}
\hline Species & Varieties & Height & Pod plant & $\begin{array}{c}\text { Seed } \\
\text { pod }^{-1}\end{array}$ & $\begin{array}{c}\text { 1000 seed } \\
\text { weight }(\mathrm{g})\end{array}$ & $\begin{array}{c}\text { Yield } \\
\left(\mathrm{t} \mathrm{ha} \mathrm{h}^{-1}\right)\end{array}$ \\
\hline L. albus & Luxor & $93.9 \mathrm{a}$ & $16.0 \mathrm{~b}$ & 3.7 & $272.7 \mathrm{a}$ & $2.4 \mathrm{a}$ \\
L. albus & Rosetta & $104.5 \mathrm{a}$ & $14.8 \mathrm{~b}$ & 3.7 & $266.7 \mathrm{a}$ & $2.0 \mathrm{a}$ \\
L. angustifolius & Wonga & $73.5 \mathrm{bc}$ & $23.4 \mathrm{ab}$ & 3.8 & $101.0 \mathrm{~b}$ & $0.5 \mathrm{c}$ \\
L. angustifolius & Jindalee & $80.1 \mathrm{~b}$ & $23.4 \mathrm{ab}$ & 3.5 & $108.0 \mathrm{~b}$ & $0.5 \mathrm{c}$ \\
L. angustifolius & Sonet & $58.9 \mathrm{~d}$ & $33.5 \mathrm{a}$ & 3.7 & $125.3 \mathrm{~b}$ & $1.5 \mathrm{~b}$ \\
L. luteus & Dukat & $71.8 \mathrm{bcd}$ & $22.7 \mathrm{ab}$ & 3.7 & $111.0 \mathrm{~b}$ & $1.4 \mathrm{~b}$ \\
L. luteus & Mister & $79.5 \mathrm{~b}$ & $19.9 \mathrm{ab}$ & 3.6 & $117.7 \mathrm{~b}$ & $1.6 \mathrm{~b}$ \\
L. luteus & Taper & $63.9 \mathrm{~cd}$ & $13.5 \mathrm{~b}$ & 3.5 & $104.3 \mathrm{~b}$ & $0.8 \mathrm{c}$ \\
\hline
\end{tabular}

Mean values with different letters are significantly different for $\mathrm{P}<0.05$.

Significant differences emerged among the species and varieties in relation to morphological and productive parameters. L. albus showed the highest values in terms of plant height $(99.2$ $\mathrm{cm}$ on average) and plant yield (2.2 $\mathrm{t} \mathrm{ha}^{-1}$ on average) and also the lowest value of pod plant ${ }^{-1}$ (Tab. 3). Dukat and Mister of L. luteus and Sonet of L. angustifolius yielded on average 1.5 $\mathrm{t} \mathrm{ha}^{-1}$, whereas the remaining cultivars never exceeded $0.8 \mathrm{t} \mathrm{ha}^{-1}$. The number of seeds pod $^{-1}$ was quite similar in all the studied varieties (3.7 on average). No correlation was found between flowering date and yield.

Yield values were in agreement with that obtained on L. albus and L. angustifolius by several authors (Postiglione et al., 1993; Pritoni, 1993; Annichiarico et al., 2003) in North and central Italy, even though a pick of production up to $4.0 \mathrm{t} \mathrm{ha}^{-1}$ were recorded. Lopez-Bellido et al., (2000), in a pluriannual trial carried out in

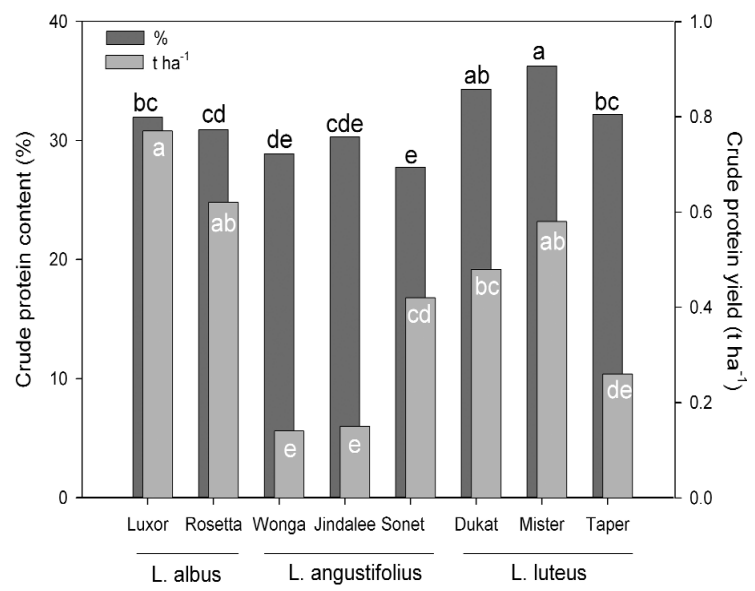

Figure 2. Crude protein content (\%) and crude protein yield $\left(\mathrm{t} \mathrm{ha}^{-1}\right)$ of the studied varieties. Different letters indicate significative value for $\mathrm{P}<0.05$. southern Spain with 60 plant $\mathrm{m}^{-2}$, found on $L$. albus comparable yield $\left(2.5 \mathrm{t} \mathrm{ha}^{-1}\right)$ and number of seeds x pod (3.4), but with a greater 1000 seed weight $(480 \mathrm{~g})$ and lower number of pods $\mathrm{x}$ plant (5.2). Higher yield (2.9 $\left.\mathrm{t} \mathrm{ha}^{-1}\right)$ was obtained in L. angustifolius by Bohm et al. (2008) in North Germany.

Among the different species of lupins (Fig. 2 ), significantly higher levels of crude protein were observed in L. luteus (34.2\%, on average). According to Gdala et al., (1996), significantly lower values of crude protein were obtained in the L. angustifolius ( $29.0 \%$, on average). Generally, the crude protein content of the studied cultivars showed lower values compared to those reported in other studies (Bohm et al., 2008; Sauvant et al., 2002; Sujak et al. 2006). Taking into account the total protein yield, L. albus, even if characterised by a lower protein percentage compared to L. luteus, showed the highest protein production reaching values of $0.7 \mathrm{tha}^{-1}$, due to its superior productive performance. This value is slightly higher compared to what obtained by Postiglione et al. (1993) in Italy, but lower as compared to Bohm et al. (2008) in Germany. The lower productive and qualitative traits recorded in our trial compared to what was obtained in central Europe may be due to the terminal drought imposed by the Mediterranean climate; including water shortages in spring and during the grain formation period which can play a prominent role in determining yield and quality (Dracup et al., 1998; Lopez-Bellido et al., 2000).

As regards the fibre fractions (Fig. 3), L. angustifolius showed higher mean values of NDF ( $28.1 \%$, on average) and ADF $(25 \%$, on average), specifically in Wonga ( $\mathrm{NDF}=31.5 \%$; $\mathrm{ADF}$ $=27.7 \%$ ), than those observed in L. luteus 


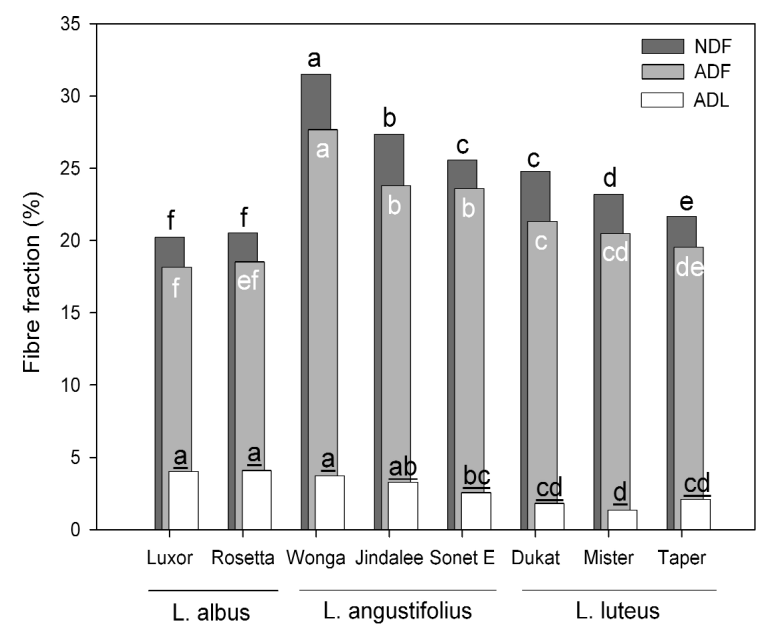

Figure 3. NDF, ADF and ADL fibre fractions (\%) of the studied varieties. Different letters indicate significative value for $\mathrm{P}<0.05$.

$(\mathrm{NDF}=23.2 \% ; \mathrm{ADF}=20.4 \%$, on average $)$ and L. albus $(\mathrm{NDF}=20.37 \%$; $\mathrm{ADF}=18.33 \%$, on average). Both cultivars of L. albus, Wonga and Jindalee of $L$. angustifolius showed significantly higher mean values of ADL (3.9\%, on average), when compared to Sonet of L. angustifolius $(2.9 \%$, on average) and L. luteus $(1.8 \%$, on average). The results concerning the fibre fractions of $L$. albus were similar to those reported by NRC (1998) for sweet white lupin, but higher than data reported by Singh et al. (1995) and by Sauvant et al. (2002). Moreover, data regarding these fractions in L. angustofolius were higher than those reported by Sauvant et al. (2002), and those regarding L. luteus were similar to those reported by Gdala et al. (1996).
As reported in Table 4, six alkaloids were detected and quantified: Sparteine, Angustifoline, Lupanine, a-Iso-lupanine, 13 a- Hydroxylupanine and 11,12-Deidrelupanine. The analysis of the results showed that the studied samples had much lower alkaloid content than that reported by Gdala et al. (1996) and Reinhard et al. (2006); these values are much lower than the safe limit of toxicity $(<0.20 \%)$, indicated for human and animal consumption by the health authorities of Great Britain, France and Australia (Boschin et al., 2008). Very low concentrations of quinolizidine alkaloids were observed in all the varieties $\left(3.0 \mathrm{mg} 100 \mathrm{~g}^{-1}\right)$ compared to the control Multitalia (166.4 mg $\left.100 \mathrm{~g}^{-1}\right)$. The Lupanine was the most represented alkaloid $(1.5 \mathrm{mg}$ $100 \mathrm{~g}^{-1}$, on average of the tested varieties), whereas, Iso-lupanine was the least represented

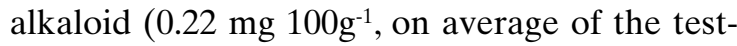
ed varieties) (table 4); these results are in agreement with the observations of Muzquiz et al. (1994) in the alkaloid profile of L. albus and with those of Boschin et al. (2008) in nine alkaloid-poor varieties of $L$. albus and $L$. angustifolius grown in two climatically contrasting Italian sites. The chromatographic analysis allowed to identify the presence of Iso-lupanine only in L. albus; in L. angustifolius and L. luteus the Iso-lupanine content was below the instrumental limit of quantification $(0.04 \mathrm{mg} 100$ $\mathrm{g}^{-1}$ ) (Tab. 4). Regardless the reported lupanine content was too low to play any important biological activity within human and animal metabolisms (Keeler, 1989). The Angustifoline, rather uncommon in L. albus, was identified in both cultivars Luxor and Rosetta as reported by

Table 4. Composition of quinolizidine alkaloids $\left(\mathrm{mg} \cdot 100 \mathrm{~g}^{-1}\right)$ in the studied varieties of lupin.

\begin{tabular}{lllllllll}
\hline Species & Varieties & 1 & 2 & 3 & 4 & 5 & 6 & 7 \\
\hline L. albus & Multitalia & $0.21 \mathrm{c}$ & $3.35 \mathrm{a}$ & $0.91 \mathrm{a}$ & $149.9 \mathrm{a}$ & $9.91 \mathrm{a}$ & $2.12 \mathrm{a}$ & $166.4 \mathrm{a}$ \\
L. albus & Luxor & ND & $0.63 \mathrm{bc}$ & $0.25 \mathrm{~b}$ & $3.3 \mathrm{~b}$ & $1.34 \mathrm{bc}$ & $2.00 \mathrm{a}$ & $7.5 \mathrm{~b}$ \\
L. albus & Rosetta & ND & $0.49 \mathrm{bc}$ & $0.18 \mathrm{~b}$ & $1.8 \mathrm{~b}$ & $0.38 \mathrm{c}$ & $0.92 \mathrm{~b}$ & $3.8 \mathrm{~b}$ \\
L. angustifolius & Wonga & ND & $0.23 \mathrm{c}$ & ND & $0.74 \mathrm{~b}$ & $0.56 \mathrm{c}$ & ND & $1.5 \mathrm{~b}$ \\
L. angustifolius & Jindalee & ND & $1.12 \mathrm{~b}$ & ND & $1.79 \mathrm{~b}$ & $2.6 \mathrm{~b}$ & ND & $5.5 \mathrm{~b}$ \\
L. angustifolius & Sonet & $0.059 \mathrm{~d}$ & ND & ND & $1.19 \mathrm{~b}$ & $0.87 \mathrm{bc}$ & ND & $2.1 \mathrm{~b}$ \\
L. luteus & Dukat & $0.97 \mathrm{ab}$ & ND & ND & ND & ND & ND & $1.0 \mathrm{~b}$ \\
L. luteus & Mister & $0.71 \mathrm{bc}$ & ND & ND & $0.05 \mathrm{~b}$ & $0.11 \mathrm{c}$ & ND & $0.9 \mathrm{~b}$ \\
L. luteus & Taper & $1.36 \mathrm{a}$ & ND & ND & ND & ND & ND & $1.4 \mathrm{~b}$ \\
\hline
\end{tabular}

(1) Sparteine, (2) Angustifoline, (3) $\alpha$-Isolupanine, (4) Lupanine, (5) 13 $\alpha$ - Hydroxylupanine, (6) 11,12-Deidrelupanine, (7) Sum of alkaloids.

Mean values with different letters are significantly different for $\mathrm{P}<0.05$.

$\mathrm{ND}=$ value below the L.O.Q. 
Table 5. Correlation matrix.

\begin{tabular}{lrrr}
\hline Variable & PC 1 & PC 2 & PC 3 \\
\hline pods plant $^{-1}$ & -0.375 & 0.626 & 0.353 \\
seeds pod $^{-1}$ & 0.185 & 0.207 & 0.899 \\
1000 seed weight & 0.934 & -0.252 & 0.215 \\
seed yield & 0.667 & -0.510 & 0.407 \\
protein & -0.163 & -0.778 & -0.203 \\
NDF & -0.512 & 0.796 & 0.110 \\
ADF & -0.508 & 0.824 & 0.158 \\
ADL & 0.779 & 0.471 & 0.091 \\
alk. 1 & -0.594 & -0.700 & -0.279 \\
alk. 2 & 0.613 & 0.506 & -0.523 \\
alk. 3 & 0.955 & -0.233 & 0.147 \\
alk. 4 & 0.940 & 0.298 & -0.044 \\
alk. 5 & 0.423 & 0.701 & -0.501 \\
alk. 6 & 0.935 & -0.208 & 0.090 \\
alk. 7 & 0.896 & 0.243 & -0.323 \\
\hline
\end{tabular}

Wink et al. (1995) and in L. angustifolius (Tab. 4). The 11,12-Deidrelupanine was quantified only in the L. albus, whereas, in the other species was below the instrumental limit of quantification $\left(0.04 \mathrm{mg} 100 \mathrm{~g}^{-1}\right)$.

Even if a pair comparison among tested species and Multitalia, used as control, was not possible since this last crop was not cultivated in the same environment, on the whole, the quinolizidine alkaloids of the 8 sweet cultivars belonging to Lupinus albus, L. angustifolius and L. luteus showed considerably lower values. A large part of this difference may be ascribed to the remarkable breeding improvement of the new varieties.

To identify patterns in our data set and to express the data in such a way as to highlight its similarities and differences, we applied the multivariate statistical technique of the Principal Components Analysis. PCA showed three principal components accounting, as a whole, for $89.2 \%$ of the total data variability. The first one, which explained $46.9 \%$ of the variation, was associated mainly with productive traits (1000 seed weight and yield), ADL fraction and with the majority part of the alkaloids detected; component two, responsible for $29.2 \%$ of the variation, was mainly represented by protein, NDF and ADF; component three contributed for $13.1 \%$ of the variation and it is exclusively associated with seed pod $^{-1}$ character (Tab. 5). The graphic representation of the relationships among varieties and parameters shows an evident distinction among the species (Fig. 4). L. luteus clearly stand out for high negative PC1 and PC2 values, corresponding mainly to high protein content and low alkaloid content, except for alkaloid 1. L. angustifolius showed high PC2 values, mainly associated with low protein content and high NDF and ADF fractions. L. albus was characterized by a high value of PC1 linked

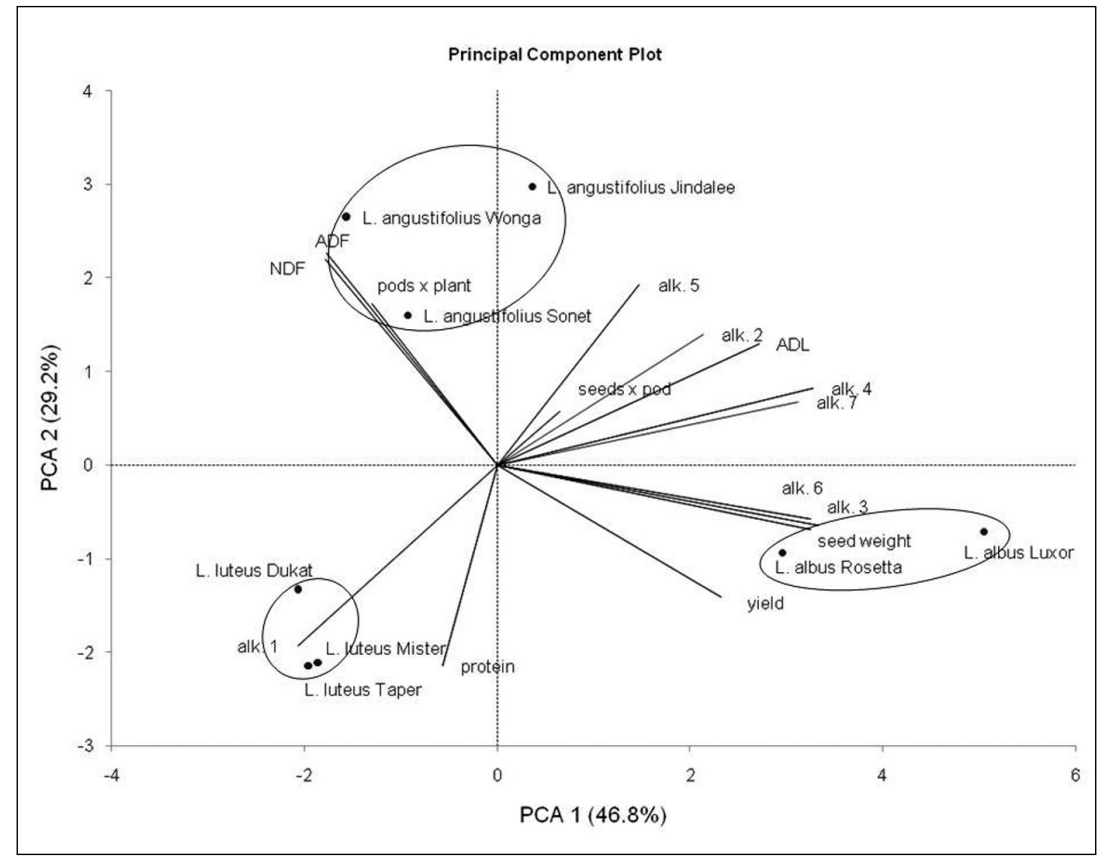

Figure 4. Scatter plot of the studied varieties based on $\mathrm{PC} 1$ and PC2. The rays connecting the traits to the biplot origin are referred to as trait vectors. The vector length of a trait measures the magnitude of its effect (positive or negative). 
with high seed production and 1000 seed weight as well as the presence of Isolupanine and Deidrelupanine alkaloid.

\section{Conclusions}

Both L. albus varieties (Luxor and Rosetta) emerged with the highest grain and protein yields. Mister and Dukat of L. luteus were interesting not only for their high protein content, but also for their low lignin and total alkaloid content.

On the whole, our data confirms the possibility of using lupin as an alternative protein source in the Mediterranean crop-livestock food chain, in particular in organic husbandry where the feed represents a restraining factor due to the ban of using GM feeds.

\section{Acknowledgment}

We are grateful to Giovanni La Malfa for its technical support in field data collection.

\section{References}

Abbate V. 2001. Rilanciamo le leguminose da granella secca. L'Informatore Agrario, 39:59-64.

Annicchiarico P., Iannucci A., Filippi L. 2003. Cultivar di colture proteiche a confronto in areali contrastanti. L'Informatore Agrario, 42:73-77.

Annicchiarico P., Carroni A.M. 2009. Diversity of white and narrow-leafed lupin genotype adaptive response across climatically-contrasting Italian environments and implications for selection. Euphytica, 166:71-81.

A.O.A.C. 2005. Official Methods of Analysis. $18^{\text {th }}$ ed. Association of Official Analytical Chemists, Arlington, VA, USA.

Arnoldi A. 2004. Food ingredients and health benefits from sweet lupin proteins - Healthy profood. Grain Legumes, 39 - 2ns quarter, 18-19.

Arnoldi A. 2005. Optimized processes for preparing healthy and added value food ingredients from lupin kernels, the European protein-rich grain legume. Ed. Aracne, Roma.

Arnoldi A. 2007. The Healthy-Profood project: overview and main outputs. www.grainlegumes.com.

Böhm H., Bramm A., Aulrich K. Rühl G. 2008. Yield and predicted feed quality of different german cultivars of blue lupins (Lupinus angustifolius). Palta and Beger (eds.): Proceedings $12^{\text {th }}$ international Lupin conference, 14-18 Sept., Fremantle, Western Australia, 118-122.
Boschin G. Annicchairico P., Resta D., D’Agostina A., Arnoldi A. 2008. Quinolizidine Alkaloids in Seeds of Lupin Genotypes of Different Origins. J. Agric. Food. Chem., 56:3657-3663.

Carrouée B., Crepon K., Peyronnet C. 2003. Les protéagineux: intérêt dans les systèmes de production fourragers français et européens. Fourrages, 174:163-182.

Council Regulation (EC) No. 1804/1999 of 19 July 1999 supplementing Regulation (EEC) No 2091/91 on organic production of agricultural products and indications referring thereto on agricultural products and ffodstuffs to include livestock production.

Dracup M., Kirby E.C.M. 1996. Lupin development guide. Univ. of Western Australia Press, Perth, Western Australia.

Dracup M., Reader M.A., Palta J.A. 1998. Variation in yield of narrow-leafed lupin caused by terminal drought. Aust. J. Agric. Res., 49:799-810.

Dronne Y. 2003. L'approvisionnement en protéines de la France dans son contexte européen et mondial. Fourrages, 174:107-128.

Duranti M., Consonni A., Magni C., Sessa F., Scarafoni A. 2008. The major proteins of lupin seed: characterisation and molecular properties for use as functional and nutraceutical ingredients. Trend in Food Science \& Technology, 19:624-633.

El-Adawy T.A., Rahma E.H., El-Bedawey A.A., Gafar A.F. 2001. Nutritional potential and functional properties of sweet and bitter lupin seed protein isolates. Food Chemistry, 74:455-462.

European Commission Decisions No. 98/272/CE regarding the surveillance of transmissible spongiform encephalopaties modified by the Council Directive of 5 June 2000 No. 2000/374/CE.

European Commission Decision 2006. http://eur-lex.europa.eu/LexUriServ/site/en/oj/2006/1_368/1_368200612 23en01100111.pdf.

Faostat 2009. Food and agriculture organization of the united nations. http://faostat.fao.org/.

Froidmont E., Bartiaux-Thill N. 2004. Siutability of lupin and pea seeds as a substitute for soyabean meal in highproducting dairy cow feed. Anim. Res., 53:475-487.

Gdala J., Jansman A.J.M., van Leeuwen P., Huisman J., Verstegen M.W.A. 1996. Lupinus (L. luteus, L. albus, L. angustifolius) as a protein source for young pigs. Anim. Feed Sci. and Technol., 62:239-249.

Graham K.K., Kerley M.S., Firman J.D., Allee G.L. 2002. The effect of enzyme treatment of soybean meal on oligosaccharide disappearance and chick growth performance. Poultry Sci., 81:1014-1019.

Hill G.D. 1977. The composition and nutritive value of lupin seed. Nutr. Abst. Rev., 47:511-519.

Jensen E.S., Hauggaard-Nilesen H. 2003. How can increased use of biological $\mathrm{N}_{2}$ fixation in agriculture benefit the environment? Plant Soil, 252:177-186.

Keeler R.F. 1989. Quinolizidine alkaloids in range and 
grain lupins. In: Cheeky P.R. (ed.): Toxicant of plant origin, 335 pp., Vol. I, Alkaloids, 133-167. CRC, Press, Boca Raton, FL.

Kerley M.S., Allee G.L. 2003. Modifications in soybean seed composition to enhance animal feed use and value: moving from a dietary ingredient to a functional dietary component. AgBioForum, 6, 1\&2:14-17.

Lopez-Bellido L., Fuentes M., Castillo J.E. 2000. Growth and Yield of White Lupin Under Mediterranean Conditions: Effect of Plant Density. Agronomy Journal, 92:200-205.

Muzquiz M., Cuadrado C., Ayet G., de la Cuadra C., Burbao C., Osagie A. 1994. Variation of Alakaloid component of Lupin seeds in 49 Genotypes of Lupinus albus L. from different Countries and Locations. J. Agric. Food Chem., 42:1447-1450.

Nossack A.C., Vilegas J.H.Y., von Baer D., Lancas F.M. 2000. Supercritical fluid extraction and Chromatographic analysis (HRGC-FID and HRGC-MS) of Lupinus spp. Alkaloids. J. Braz. Chem. Soc., 11, 5:495501.

NRC - National Research Council 1998. Nutrient Requirements of Swine. $10^{\text {th }}$ edn. National Academy Press, 155, Washington, DC.

Oboh H.A., Muzquiz M., Burbano C., Cuadrado C., Pedrosa M.M., Ayet G., Osagie A.U. 1998. Anti-nutritional constituents underutilized legumes grown in Nigeria. J. Chrom., 823:307-312.

Postiglione L., Fagnano M., Cozza C. 1995. Prove di rotazioni: effetto delle colture di mais (Zea mais L.) frumento (Triticum durum Desf.) e lupino dolce (Lupinus albus L.) sulle caratteristiche quali-quantitative della produzione e sul suolo. Riv. Agron., 3 suppl.:434441.

Postiglione L., Lanza A.M.R., Fagnano M., Cozza C. 1993. Comportamento di varietà e linee di Lupinus albus L. povere di alcaloidi nella piana del Sele. In: Istituto di Agronomia generale e Coltivazioni erbacee, Università di Catania (ed.): Le leguminose da granella in Italia, 325-331.

Pritoni G. 1993. Comportamento produttivo del lupino nella pianura emiliana. In: Istituto di Agronomia generale e Coltivazioni erbacee, Università di Catania (ed.): Le leguminose da granella in Italia, 333-336.

Reinhard H., Rupp H., Sager F., Streule M., Zoller O. 2006. Quinolizidine alkaloids and phomopsins in lupin seeds and lupin containing food. J. of Chromat. A, 1112:353-360.

Sauvant D., Perez J.-M., Tran G. 2002. Tables de composition et de valeur nutritive des matières premières destinées aux animaux d'élevage. 301. INRA éditions, Paris Cedex 07.

Scarafoni A., Sironi E., Duranti M. 2007. Tracing lupin in food ingredients and end-products. www.grainlegumes.com.

Singh C.K., Robinson P.H., McNiven M.A. 1995. Evaluation of raw and roasted lupin seeds as protein supplements for lactating cows. Anim. Feed Sci. and Technol., 52:63-76.

Sirtori C.R., Lovati M.R., Manzoni C.M., Castiglioni S., Duranti M., Magni C., Moranti S., D’Agostina A., Arnoldi A. 2004. Proteins of white lupin seed, a naturally isoflavone-poor legume, reduce cholesterolemia in rats and increase LDL receptor activity in HepG2 cells. J. Nutr., 134:18-23.

Sujak A., Kotlarz A., Strobel W. 2006. Compositional and nutritional evaluation of several lupin seeds. Food Chemistry, 98:711-719.

van Barnelveld R.J. 1999. Understanding the nutritional chemistry of lupin (Lupinus spp.) seed to improve livestock production efficency. Nutr. Res. Rev., 12:203230.

Vicenti A., Toteda F., Di Turi L., Cocca C., Perrucci M., Melodia L., Ragni M. 2009. Use of sweet lupin (Lupinus albus L. var. Multitalia) in ffeding for Podolian young bulls and influence on productive performances and meat qualità traits. Meat Science, 82:247251.

Wink M. 1988. Plant breeding: importance of plant secondary metabolites for protection against pathogens and herbivores. Theor. Appl. Genet., 75:225-233.

Wink M., Meibner C., Witte L. 1995. Pattern of quinozidoline alkaloids in 56 species of the genus Lupinus. Phytochemistry, 38:139-153.

Woodworth J.C., Tokach M.D., Goodband R.D., Nelssen J.L., O’Quinn P.R., Knabe D.A., Said N.W. 2001. Apparent ileal digestibility of amino acids in the digestible and metablizable Energy content of dry extruded-expelled soybean meal and its effects on growth performance of pigs. J. Anim. Sci., 79:12801287. 